\title{
Identification of Influencers in Social Media using Social Network Analysis (SNA)
}

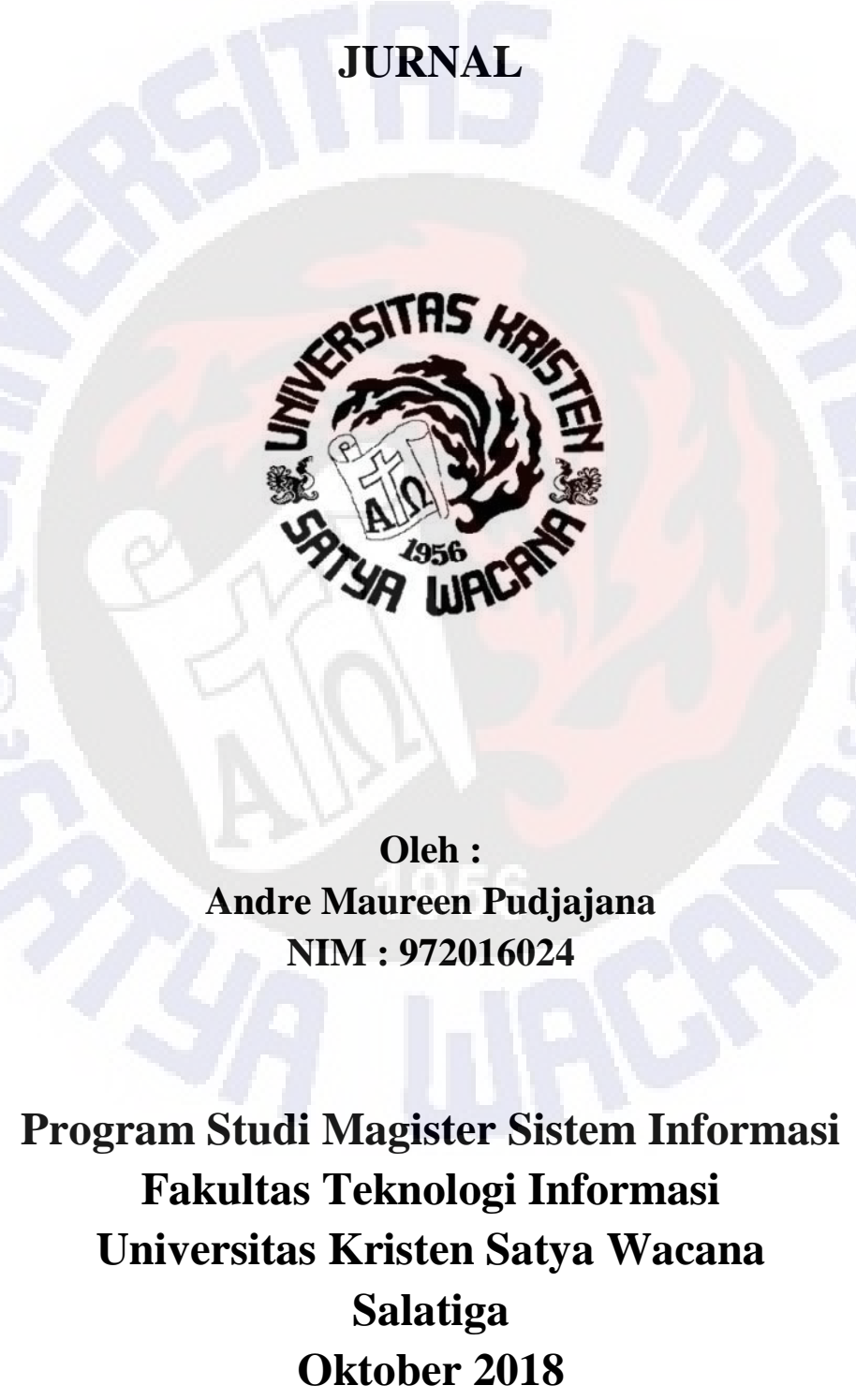


Identification of Influencers in Social Media using Social

Network Analysis (SNA)

\section{JURNAL}

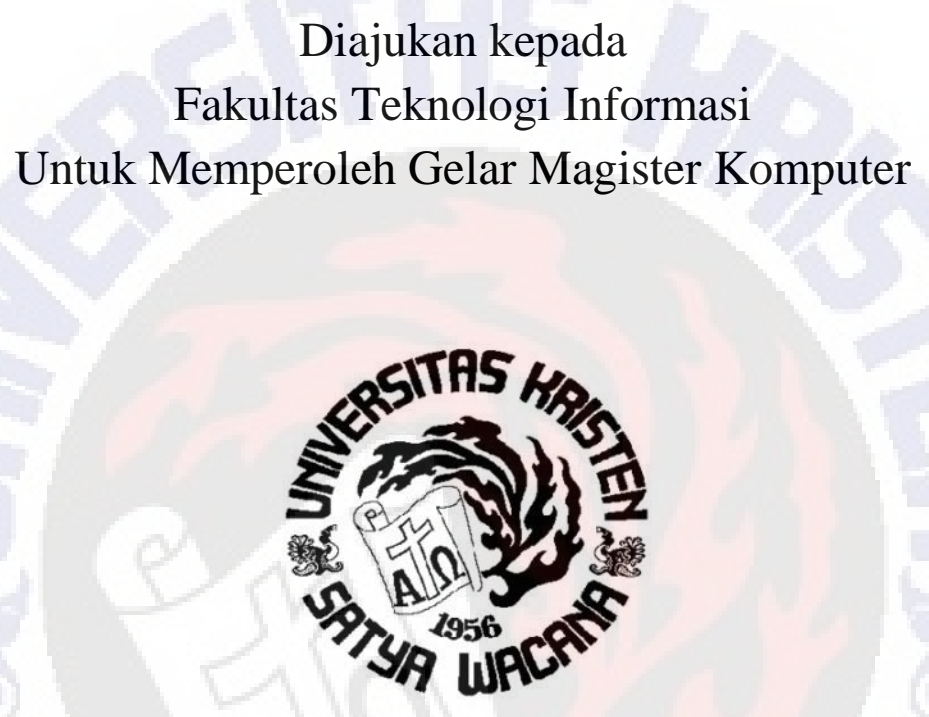

Oleh :

Andre Maureen Pudjajana

NIM : 972016024

Program Studi Magister Sistem Informasi

Fakultas Teknologi Informasi

Universitas Kristen Satya Wacana

Salatiga

Oktober 2018 
PERPUSTAKAAN UNiversitas UNIVERSITAS KRISTEN SATYA WACANA

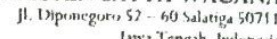
Tclp, 0298 Jatra lengah, Frolonicsia Finaif: likrary (ât) adin

\section{PERNYATAAN TIDAK PLAGIAT}

Saya yang bertanda tangan di bawah ini:

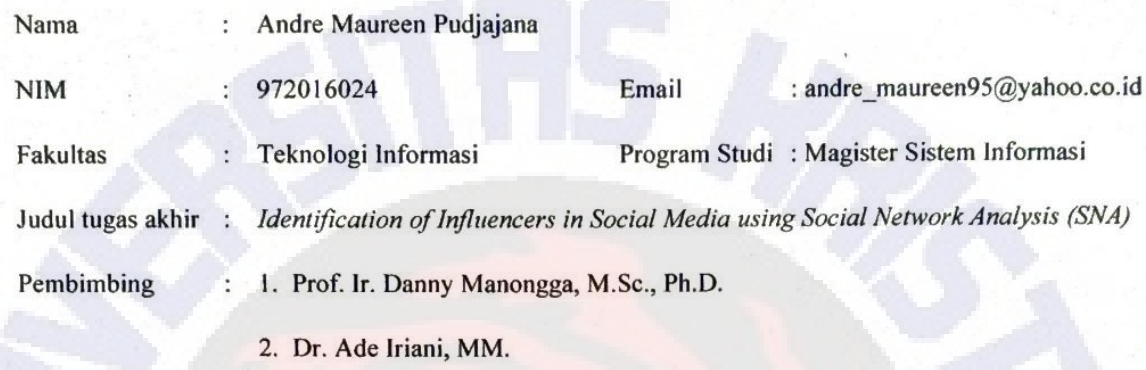

Fakultas

Judul tugas akhir : Identification of Influencers in Social Media using Social Network Analysis (SNA)

Pembimbing : $\quad$ 1. Prof. Ir. Danny Manongga, M.Sc., Ph.D.

2. Dr. Ade Iriani, MM.

Dengan ini menyatakan bahwa:

1. Hasil karya yang saya serahkan ini adalah asli dan belum pernah diajukan untuk mendapatkan gelar magister baik di Universitas Kristen Satya Wacana maupun di institusi pendidikan lainnya.

2. Hasil karya saya ini bukan saduran/terjemahan melainkan merupakan gagasan, rumusan, dan hasil pelaksanaan penelitian/implementasi saya sendiri, tanpa bantuan pihak lain, kecuali arahan pembimbing akademik dan narasumber penelitian.

3. Hasil karya saya ini merupakan hasil revisi terakhir setelah diujikan yang telah diketahui dan disetujui oleh pembimbing.

4. Dalam karya saya ini tidak terdapat karya atau pendapat yang telah ditulis atau dipublikasikan orang lain, kecuali yang digunakan sebagai acuan dalam naskah dengan menyebutkan nama pengarang dan dicantumkan dalam daftar pustaka.

Pernyataan ini saya buat dengan sesungguhnya. Apabila di kemudian hari terbukti ada penyimpangan dan ketidakbenaran dalam pernyataan ini maka saya bersedia menerima sanksi akademik berupa pencabutan gelar yang telah diperoleh karena karya saya ini, serta sanksi lain yang sesuai dengan ketentuan yang berlaku di Universitas Kristen Satya Wacana.

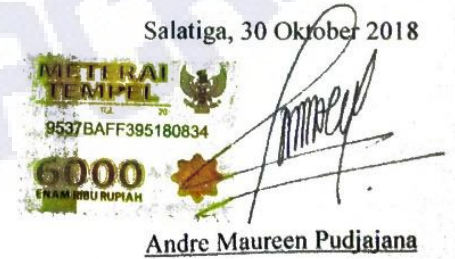


PERPUSTAKAAN UNIVERSITAS UNIVERSTTAS KRISTEV SATYA WACANA

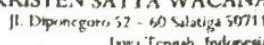

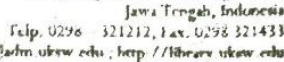

\section{PERNYATAAN PERSETUJUAN AKSES}

Saya yang bertanda tangan di bawah ini:

Nama : Andre Maureen Pudjajana

NIM 972016024

Email

: andre_maureen95@yahoo.co.id

Fakultas

: Teknologi Informasi

Program Studi : Magister Sistem Informasi

Judul tugas akhir : Identification of Influencers in Social Media using Social Network Analysis (SNA)

Dengan ini saya menyerahkan hak non-eksklusif* kepada Perpustakaan Universitas - Universitas Kristen Satya Wacana untuk menyimpan, mengatur akses serta melakukan pengelolaan terhadap karya saya ini dengan mengacu pada ketentuan akses tugas akhir elektronik sebagai berikut (beri tanda pada kotak yang sesuai):

$\checkmark$ a. Saya mengijinkan karya tersebut diunggah ke dalam aplikasi Repositori Perpustakaan Universitas, dan/atau portal GARUDA

b. Saya tidak mengijinkan karya tersebut diunggah ke dalam aplikasi Repositori Perpustakaan Universitas, dan/atau portal GARUDA**

* Hak yang tidak terbatas hanya bagi satu pihak saja. Pengajar, peneliti, dan mahasiswa yang menyerahkan hak non-ekslusif kepada Repositori Perpustakaan Universitas saat mengumpulkan hasil karya mereka masih memiliki hak copyright atas karya tersebut.

** Hanya akan menampilkan halaman judul dan abstrak. Pilihan ini harus dilampiri dengan penjelasan alasan tertulis dari pembimbing $T$ dan diketahui oleh pimpinan fakultas (dekankaprodi).

Demikian pernyataan ini saya buat dengan sebenarnya.

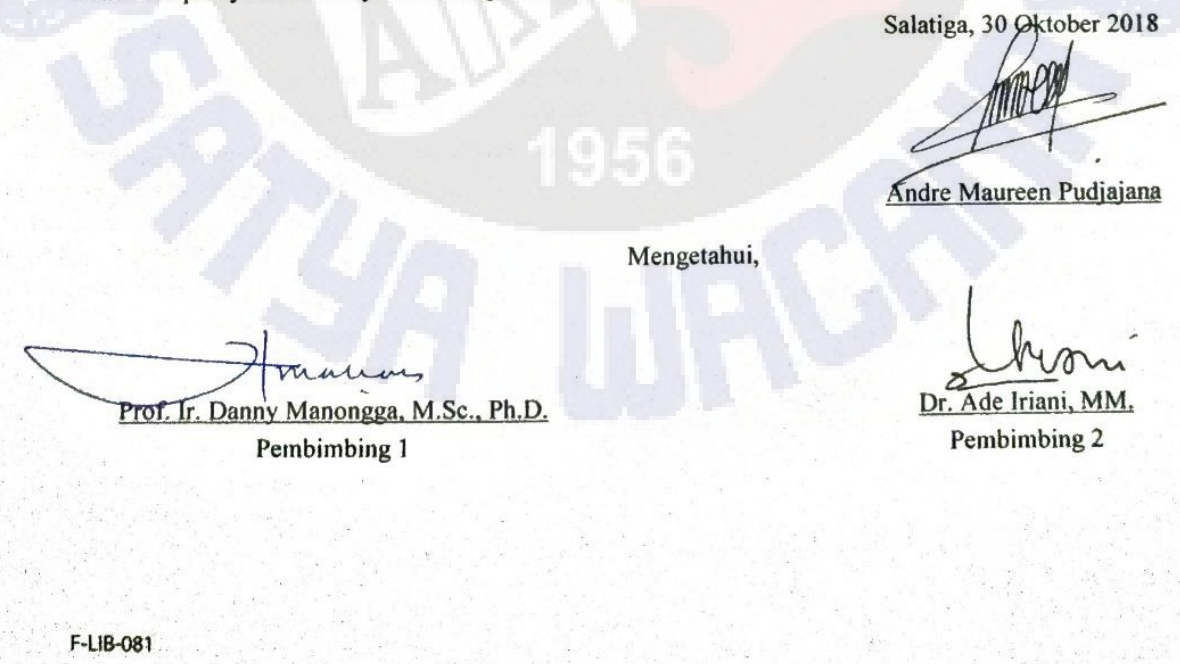




\title{
Identification of Influencers in Social Media using Social Network Analysis (SNA)
}

\author{
Oleh,
}

Andre Maureen Pudjajana

NIM : 972016024

\section{ARTIKEL ILMIAH}

Diajukan kepada

Fakultas Teknologi Informasi

untuk Memperoleh Gelar Magister Komputer

\section{Disetujui oleh,}

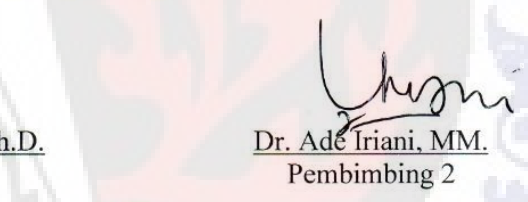

Dekan

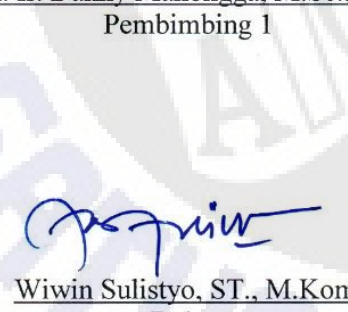

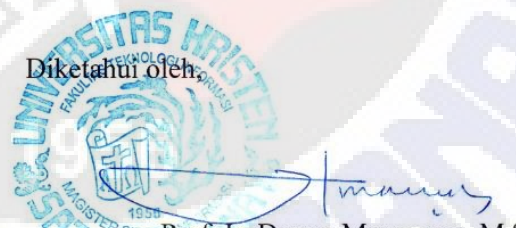

Ketua Program Studi

Program Studi Magister Sistem Informasi

Fakultas Teknologi Informasi

Universitas Kristen Satya Wacana

Salatiga

2018 


\section{Lembar Pengesahan}

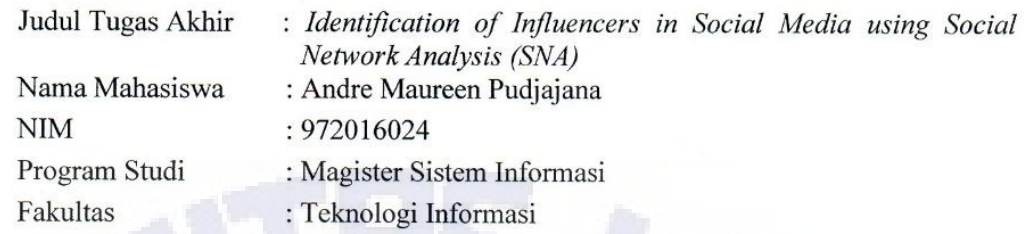

Program Studi : Magister Sistem Informasi

Fakultas : Teknologi Informasi

\section{Menyetujui,}

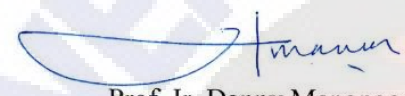

Prof. Ir. Danny Manongga, M.Sc., Ph.D. Pembimbing 1

\section{T.75} Méngessoghlikan

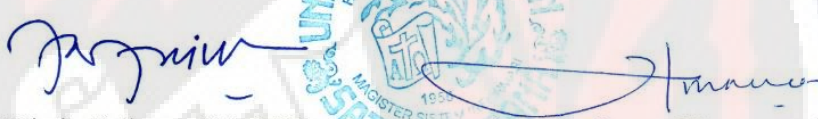

Dr. Ade Iriani, MM. Pembimbing 2

Wiwin Sulistyo, ST., M.Kom. Dekan

Prof. Ir. Danny Manongga, M.Sc., Ph.D. Ketua Program Studi

Dinyatakan Lulus Tanggal: 29 Oktober 2018

Penguji :

- Prof. Dr. Ir. Eko Sediyono, M.Kom.

- Dr. Irwan Sembiring, ST., M.Kom.

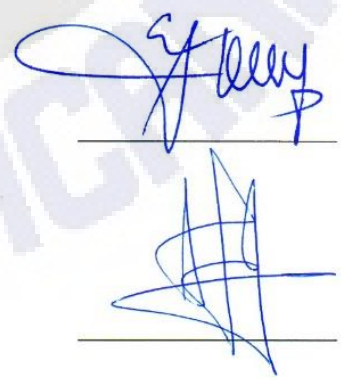




\section{Kata Pengantar}

Puji syukur kepada Tuhan Yang Maha Esa atas kasih dan penyertaanNya sehingga peneliti dapat menyelesaikan penelitian yang berjudul "Identification of Influencers in Social Media using Social Network Analysis (SNA)". Adapun penelitian tersebut diajukan sebagai persyaratan dalam menyelesaikan studi S2 di Magister Sistem Informasi pada Fakultas Teknologi Informasi, Universitas Kristen Satya Wacana dan meraih gelar Magister Komputer.

Dalam kesempatan ini, penulis mengucapkan terimakasih kepada semua pihak yang telah membantu sehingga penelitian ini dapat terselesaikan tepat pada waktunya. Ucapan terimakasih ini penulis berikan kepada

1. Bapak Wiwin Sulistyo, ST., M.Kom., selaku Dekan Fakultas Teknologi Informasi Universitas Kristen Satya Wacana.

2. Bapak Prof. Ir. Danny Manongga, M.Sc., Ph.D., selaku Ketua Program Studi Magister Sistem Informasi, Fakultas Teknologi Informasi Universitas Kristen Satya Wacana.

3. Bapak Prof. Ir. Danny Manongga, M.Sc., Ph.D. dan Ibu Dr. Ade Iriani, MM., selaku pembimbing yang telah meluangkan waktu untuk membimbing dan juga memberi saran, kritik, serta motivasi sehingga penelitian ini dapat selesai dengan baik dan tepat pada waktunya. Semoga damai sejahtera dan berkat dari Tuhan Yang Maha Kuasa selalu menyertai pembimbing dan keluarga.

4. Bapak Hindriyanto Dwi Purnomo, ST., MIT., Ph.D. dan Bapak Dr. Irwan Sembiring, ST., M.Kom., yang telah memberikan projek hibah penelitian DIKTI kepada peneliti. Selain itu juga, telah membimbing peneliti sehingga peneliti dapat menyelesaikan penelitian ini dengan 
baik. Semoga damai sejahtera dan berkat dari Tuhan Yang Maha Kuasa selalu menyertai pembimbing dan keluarga.

5. Semua Bapak dan Ibu Dosen dan staff Fakultas Teknologi Informasi Universitas Kristen Satya Wacana yang telah membantu peneliti selama proses kuliah.

6. Papa dan Mama serta seluruh keluarga besar yang selalu mendoakan kelancaran kuliah dan memberi semangat pantang menyerah.

7. Semua teman yang turut membantu dan menyemangati peneliti selama kuliah.

Akhir kata, peneliti berharap penelitian ini dapat bermanfaat bagi pembaca sekalian.

Salatiga, 30 Oktober 2018

Andre Maureen Pudjajana 


\section{Identification of Influencers in Social Media using Social Network Analysis (SNA)}

\author{
Andre Maureen Pudjajana \\ Faculty of Information \\ Technology \\ Satya Wacana Christian \\ University \\ Salatiga, Indonesia \\ 972016024@student.uksw.edu
}

\author{
Danny Manongga \\ Satya Wacana Christian \\ University \\ Salatiga, Indonesia \\ dmanongga@gmail.com
}

Hindriyanto Dwi Purnomo

Satya Wacana Christian

University

Salatiga, Indonesia

hindriyanto.purnomo@staff.uk sw.edu

\author{
Ade Iriani \\ Satya Wacana Christian \\ University \\ Salatiga, Indonesia \\ ade.iriani@staff.uksw.edu
}

\begin{abstract}
Social media is a communication media that is often used to connect many people around the world. The inappropriate use of social media will have a negative impact. The example is the spread of hoaxes. Hoax is a topic that shared by many accounts on social media. These accounts are referred as influencers. This research aims to identify influencers in social media. This research use hoax dataset. The methods are Social Network Analysis (SNA) and weighting of SNA measurements. The results of this study are a list of SNA measurement results which are then combined using weighting. The results indicate the social media accounts that act as the major influencers and their relationships with other accounts. The relation is shown in a model to know the path of the spread.
\end{abstract}

Keywords-influencer, hoax, social network analysis, weighting, social media

\section{INTRODUCTION}

Social media is a communication media that is often used to connect many people around the world. Social media has also become one of the sources to access the latest and emergency news around the world [1]. Some examples of social media like Facebook and Twitter are also used by some people to share experiences, daily activities, and opinions. However, social media is also a good media to spread negative news such as hoaxes, slander news, and hate news.

According to the Association of Indonesian Internet Service Provider, internet users in Indonesia in 2017 reached 143.26 million and smartphone users more than 100 million [2]. It supports everyone using social media and sharing information including hoaxes. Hoax is incorrect information that is made as if it is true to mislead others. The results of hoax survey conducted by the Indonesian Telematics Society show that hoaxes are most commonly accepted in written form. Hoaxes spread through social media like Facebook, Twitter (92.40\%), chat applications like Whatsapp, Line (62.80\%), and website (34.90\%). The survey also describes 4 topics of hoax which occupy the top 4 positions. There are social politics (91.80\%), tribe and religion (88.60\%), health (41.20\%), and food (32.60\%) [3]. 
Facebook is a social media with the number of users has reached more than 1.59 billion users [1]. Facebook provides a variety of features to interact including adding friends, liking status, commenting on status, and sharing status [4]. These interaction patterns are described with social network. Social network form graphs which each user becomes a vertex and a relation becomes edge [5]. Generally, the more relationships will make the bigger graph so that the Facebook user appears that acts as influencer.

Every Facebook user has an opportunity to become an influencer. Influencers can be interpreted as a social media user who actively shares the status of others [5]. Influencers is also a user whose presence invites other users to interact [6]. The role of influencers in social media can be divided into few categories which one of them is a hoax influencers.

Hoax influencers can be categorized into 2 parts. First, the influencers are tasked to spread all hoaxes. Second, influencers who share hoaxes accidentally. The spread of hoaxes gives many negative impacts on society and government. Some examples of such problems are disunity, political instability, crime, and insecurity [3].

Influencers in social media can be traced using Social Network Analysis (SNA) [7,8,13]. SNA provides some measurements such as Degree Centrality, Closeness Centrality, and Betweenness Centrality to know about influencers. Determination of influencers on the Facebook network is supported by number of share, like, and comment on status.

The purpose of this research is to identify hoax influencers on social media using SNA. This research will focus on the measurement of Degree Centrality, Closeness Centrality, and Betweenness Centrality. These measurements have been used by previous studies with various combination of methods for finding influencers $[1,4,9]$. Each centrality measurement result will be combined with weighting to each of the centrality values in each vertex. Then the final result of the weighting will be modeled into hierarchy.

\section{LITERATURE REVIEW}

\section{A. Previous Studies}

Research on the spread of influencers has been conducted using various case studies and methods. The studies are used as a reference in this research. The first study discusses the issue of the spread of influencers that have positive and negative impacts. Any influencer in social networks can be found using SNA. The calculation uses Local Centrality with a Coefficient (CLC). The results of CLC comparisons with Degree Centrality, Betweenness Centrality, Closeness Centrality, K-Shell, and Local Centrality indicate that CLC has an effective value in determining influencers in social networks [8].

The second study discusses the issue of influencers in social media and detects the relationships of social media users. The method used is SNA and Association Rule (AR). The result of this study is to find the relationship of all users in the dataset using $A R$. Then it determines the influencers based on the many user activities that appear in the relationship. The result will be combined with the measurement of the Centrality Degree and Page Rank of the SNA to find the true influencers [4].

The third study discusses identifying influencers in criminal organizations and finding influencer leader in organization. The study used ECLfinder to conduct forensic analysis to solve the criminal problem. In addition, the ECLfinder is combined with the 
Minimum Spanning Tree and SNA measurements (Degree Centrality, Closeness Centrality, and Betweenness Centrality) to find the influencers. The results show some important vertices that act as influencers and influencer leader [9].

In contrast to previous studies, this research will identify influencers using SNA and weighting. Weighting is used to combine SNA measurements (Degree Centrality, Closeness Centrality, and Betweenness Centrality). The result will be one solution to get the major influencer and spread model.

\section{B. Social Network Analysis (SNA)}

The SNA method is a method that studies the relationship between one node to another node $[10,11]$. The benefits of the SNA method include: (1) identifying individuals, teams, or units that play a major role in a network, (2) helping to accelerate the flow of knowledge on a problem, (3) improving innovation and strategies for dealing with a problem $[10,12]$.

SNA methods are used to solve a variety of problems such as finding influencers in social media [14], determining emergency matters in disasters [1], and knowing the firms employees and marketing relationships $[15,16]$. In general, each network forms a graph which each individual or group becomes vertex and the relation becomes edge [5]. The established graph will be processed using SNA measurement including Degree Centrality, Closeness Centrality, and Betweenness Centrality [8].

Here are three SNA measurements to be used in this research:

- Degree Centrality (DC). DC is used to determine the number of edges that connected to vertices $[1,13]$. Each vertex has a different $D C$ value with the other vertices. The DC measurement formula is

$$
D C(i)=\sum_{j=1}^{n} a_{i j}
$$

where $n$ is the total number of vertices and $a_{i j}$ is the number of relations from vertex $i$ to $j$.

- Closeness Centrality (CC). CC is used to find the shortest distance of all vertices to a vertex destination [13]. CC value will affect to the relationship in the network which the higher amount of CC value of a vertex then the more influential vertex is. The CC measurement formula is

$$
C C(i)=\frac{1}{\sum_{j=1}^{n} d(i, j)}
$$

where $n$ is the total number of vertices and $d(i, j)$ is the number of minimum distance from vertex $i$ to $j$.

- Betweenness Centrality (BC). BC is used to determine the shortest number of all vertices passing through a vertex [12]. The $\mathrm{BC}$ measurement formula is

$$
B C(i)=\frac{\sum_{i \neq j \neq l} g_{j l}(i)}{g_{j l}}
$$

where $g_{j l}$ is the shortest number of paths from vertex $j$ to $l$. While $g_{j l}(i)$ is the number of paths from vertex $j$ to $/$ that pass vertex $i$.

\section{METHODOLOGY}

This study uses hoax data from social media as a dataset. The dataset is used to find influencers and model of spread by influencers in social media. The method of collecting and processing data is

- Determining hoax news based on Turn Back Hoax. Turn Back Hoax is a website that contain validated hoax news. 
- Collect hoax datasets from Facebook such as like, comment, and share from Facebook status.

- $\quad$ Create a graph from the dataset. Every Facebook user becomes a vertex and relations (like, comment, and share) to edges.

- Use the SNA method with DC, BC, and $\mathrm{CC}$ measurements to find the temporary influencer.

- Perform weight calculations based on DC, BC, and CC.

- Analyze the calculation results to get influencer and create hierarchy model of hoax spread by influencer.

\section{RESULTS AND DISCUSSION}

This research uses hoax data from Facebook as a dataset. The dataset forms a social network. The social network is a graph consisting of vertices and edges. Each a vertex represents a Facebook account. While the edge is a relationship (like, comment, and share) between one vertex to another vertices.

The spread of Facebook status can be done with sharing feature. This research focuses on sharing feature to know the influencers spread pattern on Facebook. In addition, the graph dataset is undirected. The undirected relation focuses on all relations in the graph without seeing any incoming or outgoing relations from the vertex. The purpose of using an undirected graph is to know all users the relationship on Facebook status.

Influencer is a person who actively shares the status from another account or a person whose presence can encourage others to interact $[5,6]$. This research uses SNA and weighting of SNA results to find influencers and patterns of spread. Here are the results of the research.

- Degree Centrality (DC)

The DC measurement shows the number of edges connected to each vertex. Table $\mathrm{I}$ is the result of $\mathrm{DC}$ measurement with the top 10 vertices. While figure 1 is a relation of all vertices.

Table I shows the account 178 has the highest DC value. It shows account 178 have most relationship (like, comment, and share) compared to other accounts. DC measurement result also shows the lowest value that is 1 . Accounts with the value of DC 1 is accounts that only like or comment Facebook status. Figure 1 shows all relations in the dataset with the 10 highest DC values.

\section{TABLE I. 10 HIGHEST DC VALUE}

\begin{tabular}{|c|c|c|}
\hline No. & Account & DC Values \\
\hline 1 & 178 & 142 \\
\hline 2 & 111 & 106 \\
\hline 3 & 254 & 53 \\
\hline 4 & 945 & 49 \\
\hline 5 & 752 & 48 \\
\hline 6 & 251 & 35 \\
\hline 7 & 009 & 34 \\
\hline 8 & 424 & 32 \\
\hline 9 & 146 & 31 \\
\hline 10 & 123 & 29 \\
\hline
\end{tabular}

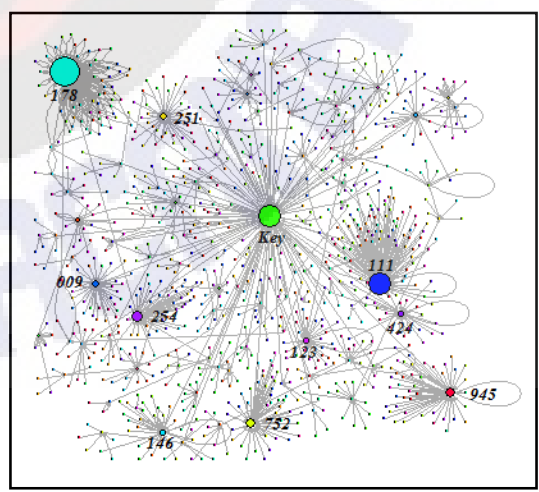

Fig. 1. Dataset Relation with 10 Highest DC Values

- Closeness Centrality (CC)

The CC measurement shows the total distance of all vertices to a vertex 
destination. Table 2 is the result of $\mathrm{CC}$ measurement with the top 10 vertices. While figure 2 is a relation of all vertices in CC.

TABLE II. 10 HIGHEST CC VALUE

\begin{tabular}{|c|c|c|}
\hline No. & Account & CC Values \\
\hline 1 & 178 & 0.0003567 \\
\hline 2 & 111 & 0.0003529 \\
\hline 3 & 061 & 0.0003417 \\
\hline 4 & 154 & 0.0003412 \\
\hline 5 & 945 & 0.0003398 \\
\hline 6 & 457 & 0.0003384 \\
\hline 7 & 009 & 0.0003379 \\
\hline 8 & 251 & 0.0003377 \\
\hline 9 & 925 & 0.0003357 \\
\hline 10 & 146 & 0.0003355 \\
\hline
\end{tabular}

Table II shows the account 178 has the highest CC value. These results indicate that account 178 has the best proximity to other accounts in spreading the hoax.The result of CC measurement also shows the lowest value that is 0.00013158 . The CC value is affected by the total distances of all vertices. If the total distance of vertex is smaller then the $\mathrm{CC}$ value will be higher. Figure 2 shows the relation graph dataset with 10 highest CC values.

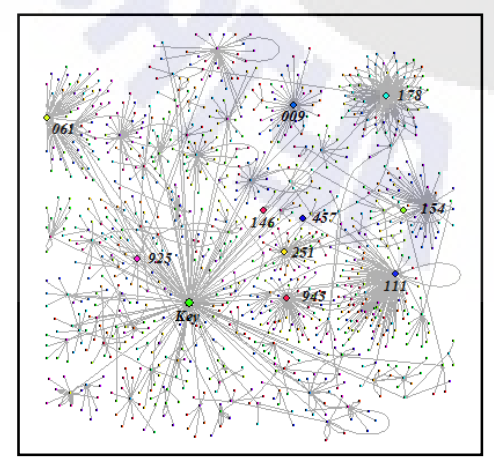

Fig. 2. Dataset Relation with 10 Highest CC Value

- Betweenness Centrality (BC)

The $\mathrm{BC}$ measurement shows the vertices that act as connecting all vertices in the graph dataset. Table 3 is the result of the $B C$ calculation with the top 10 vertices. While figure 3 is a relation of all vertices in $\mathrm{BC}$.

TABLE III. 10 HIGHEST BC VALUE

\begin{tabular}{|c|c|c|}
\hline No. & Account & BC Values \\
\hline 1 & 111 & 87742 \\
\hline 2 & 178 & 82606 \\
\hline 3 & 945 & 40076 \\
\hline 4 & 752 & 40076 \\
\hline 5 & 254 & 36866 \\
\hline 6 & 009 & 32753 \\
\hline 7 & 251 & 31837 \\
\hline 8 & 123 & 24453 \\
\hline 9 & 925 & 23249 \\
\hline 10 & 146 & 22593 \\
\hline
\end{tabular}

Table III shows the account 111 has the highest $B C$ value. 0 is the lowest value in the $B C$ measurement. $A$ value of 0 indicates that the Facebook account is not a link in the graph. High and low $B C$ values are determined from how much of the total vertices pass through one vertex. While figure 3 is the graph display of dataset relation with 10 highest $B C$ value.

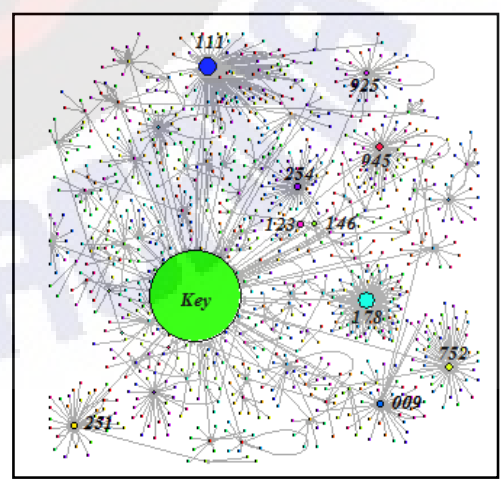

Fig. 3. Dataset Relation with 10 Highest BC Value

- Weighting of SNA Measurement Results and Spreading Influencer Models

Each SNA measurement 
generates different sequence of influencers. The purpose of weighting on SNA measurement is to know the major influencer. The different results of SNA measurements must be equated using a range of values $0-1$. The formula for creating range from $0-1$ is

$$
z=\frac{x-\min }{\max -\min }
$$

where $z$ is a new value of DC, CC, or $B C$ on each vertex. $X$ is the value of DC, CC, or BC on each vertex. Min and $\max$ are the lowest and highest values of all DC, CC, or BC values.

Each new value of $D C, C C$, and $B C$ is weighted and combined to find out the end result of each vertex. The weighting formula is

$$
y=\frac{w 1 \cdot D C+w 2 \cdot C C+w 3 \cdot B C}{w 1+w 2+w 3}
$$

where $y$ is the final value of the weighted SNA value. While $w 1, w 2$, w3 are weights with value 1 . Table IV shows the 10 highest of the final calculation.

TABLE IV. 10 VALUES OF HIGHEST END

\begin{tabular}{|c|c|c|c|c|c|}
\hline No. & Acc & $\begin{array}{c}\text { New } \\
\text { DC }\end{array}$ & $\begin{array}{c}\text { New } \\
\text { CC }\end{array}$ & $\begin{array}{c}\text { New } \\
\text { BC }\end{array}$ & $\begin{array}{c}\text { Final } \\
\text { Result }\end{array}$ \\
\hline 1 & 178 & 1 & 1 & 0.94 & 0.98 \\
\hline 2 & 111 & 0.74 & 0.98 & 1 & 0.91 \\
\hline 3 & 945 & 0.34 & 0.92 & 0.46 & 0.57 \\
\hline 4 & 752 & 0.33 & 0.92 & 0.46 & 0.57 \\
\hline 5 & 009 & 0.23 & 0.91 & 0.37 & 0.50 \\
\hline 6 & 251 & 0.24 & 0.91 & 0.36 & 0.50 \\
\hline 7 & 254 & 0.37 & 0.63 & 0.42 & 0.47 \\
\hline 8 & 146 & 0.21 & 0.90 & 0.26 & 0.46 \\
\hline 9 & 424 & 0.22 & 0.90 & 0.22 & 0.45 \\
\hline 10 & 923 & 0.13 & 0.90 & 024 & 0.42 \\
\hline
\end{tabular}

The weighted calculation result is filtered again to get the major influencer. Determination of the major influencer use a comparison of
2.5\%:97.5\% from the total of final result. $2.5 \%$ becomes the major influencer that affect $97.5 \%$ to interact in the hoax dataset. The selection of $2.5 \%$ : $97.5 \%$ is based on searches directly to the datasets that have been collected. 2.5\% are accounts with the most share relationships. While $97.5 \%$ are account the more related through likes and comments.

According to table IV, accounts included in the $2.5 \%$ amount are 178 , 111, 945, 752, 009, and 251. These accounts can be modeled in hierarchy to be example of spread pattern. Figure 4 shows the hierarchy model by the major influencers.

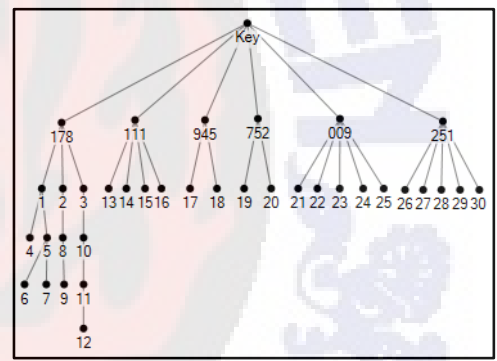

Fig. 4. The Influencer Hierarchy Model

The hierarchical model in figure 4 shows example of hoax spreading patterns through the major influencers. The results show that several major influencers have different spread patterns. In addition, each spread pattern has different support accounts. One support of the spread pattern is the relationship of friendship between accounts. For example, account 178 be friends with accounts 1, 2, and 3 so that accounts 1,2 , and 3 share from account 178 and go on.

Weighting and modeling 
hierarchy results help to identify influencers and find active accounts in the graph. In addition, the hierarchical model provides information about the spread paths. The results of this identification can be one solution in eradicating influencer hoax accounts on social media.

\section{CONCLUSION}

Conclusions of this research are influencer detection can be performed using SNA measurements (DC, CC, BC) and weighting on the SNA measurement. SNA measurement results produce different influencers list. Weighted SNA measurements serve to calculate SNA measurements and generate accounts from highest to lowest values. The determination of the influencer accounts is based on a comparison $2.5 \%$ : 97.5\%. $2.5 \%$ become the major influencers that affect $97.5 \%$ to interact in that status.

The result of this research is hierarchical model of $2.5 \%$ accounts. The established hierarchy model generates a spread path model and support accounts that involved actively in spreading the hoax. Thus, the results of identification can be one way to eradicate negative influencers in social media.

\section{REFERENCES}

[1] J. Kim and M. Hasta, "Social Network Analysis: Characteristics of Online Social Networks after A Disaster," International Journal of Information Management, vol. 38, no 1, pp. 86-96, 2018.

[2] Daily Social, “APJII: Penetration of Indonesian Internet Users Reaches 143 Million People," 2018. Available: https://dailysocial.id/post/apjii-survei-internetindonesia-2017. [Accessed July 9, 2018].

[3] Indonesia Telematics Society (MASTEL), "Infographics of MASTEL Survey Results About the National Hoax Outbreak, ” 2017. Available: http://mastel.id/infografis-hasil-surveymastel-tentang-wabah-hoax-nasional/. [Accessed July 9, 2018].
[4] F. Erlandsson, P. Brodka, A. Borg, and H. Johnson, "Finding Influential Users in Social Media using Association Rule Learning," Entropy Journal, vol. 18, no. 5, pp.164-178, 2016.

[5] M. Kaple, "Influence Detection and Spread Estimation in Social Networks," SJSU Scholar Works, 2016.

[6] J. Cossu, N. Dugue, and V. Labatut, "Detection Real-World Influence Through Twitter," IEEE 2015 Second European Network Intelligence Conference, pp. 83-90, 2015.

[7] J. Sunil More and C. Lingam, "A SI Model for Social Media Influence Maximization," Applied Computing and Informatics, 2017.

[8] X. Zhao, F. Liu, J. Wang, and T. Li, "Evaluating Influential Nodes in Social Networks by Local Centrality with A Coefficient," International Journal of GeoInformation, vol. 6, no.2, pp. 35-45, 2017.

[9] K. Taha and P. D. Yoo, "Using the Spanning Tree of a Criminal Network for Identifying Itd Leaders," IEEE Transactions on Information Forensics and Security, vol. 12, no. 2, pp. 445453, 2017.

[10] O. Serret, Knowledge Solutions Tools, Methods, and Approaches to Drive Organizational Performance, Singapore: Springer, 2017.

[11] H. Bansal, G. Shrivastava, G. Nhu Nguyen, and L. M. Stanciu, Social Network Analytics for Contemporary Business Organizations, United States of America: IGI Global, 2018.

[12] B. Empy Giri, D. Manongga, and A. Iriani, "Using Social Network Analysis (SNA) to Analyze Collaboration between Students (Case Study: Students of Open University in Kupang)," International Journal of Computer Applications, vol. 85, no.1, pp. 44-49, 2014.

[13] J. Puibgo, C. Monica, G. Sanchez-Hernandez, and N. Agell, "Influencer Detection Approaches in Social Networks: A Current State of the Art," CCIA, 2014.

[14] C. Francalanci and A. Hussain, "A Visual Analysis of Social Influencers and Influence in Tourism Domain," Information and Communication Technologies in Tourism 2015, pp. 19-32. 2015.

[15] A. Iriani, "Using Social Network Analysis to Analyze Collaboration in Batik Smes," Journal of Knowledge Management, Economics, and Information Technology, vol. 3, no. 6, pp. 1-6, 2013.

[16] S. Badi, L. Wang, and S. Pryke, "Relationship Marketing in Guanxi Networks: A Social Network Analysis Study of Chinese Construction Small and Medium-sized Enterprises," Industrial Marketing Management, vol. 60, pp. 214-218, 2017. 


\section{LETTER OF ACCEPTANCE}

International Seminar on Research of Information Technology and Intelligent Systems 2018

STMIK AKAKOM YOGYAKARTA, INDONESIA

$21-22$ November 2018

$10^{\text {th }}$ September 2018

Primary Author Andre Pudjajana, Daniel Manongga, Ade Iriani, \&

Hindriyanto D Purnomo

(Satya Wacana Christian University, Indonesia)

\begin{tabular}{ll}
\hline Paper Title & Identification of Influencers in Social Media using Social Network \\
& Analysis (SNA)
\end{tabular}

Dear Author(s),

Congratulations on the acceptance of your paper! And thank you for your interest in the $2^{\text {nd }}$ International Seminar on Research of Information Technology and Intelligent Systems 2018 (ISRITI-2018).

On behalf of the Conference Advisory Committee, I would like to formally invite you to attend the ISRITI-2018 to present your paper.

The purpose of the conference is to bring together researchers from around the world who are interested in exploring the link between information and communication technology and also intelligent system. The conference will focus on topics such as data \& distributed computing, Etechnology \& Information, Internet service applications \& technology, computer networksecurity-privacy, and smart-autonomous system.

The conference will be held at Grand Zuri Malioboro Hotel, Mangkubumi Street No. 18, Yogyakarta, Indonesia 55233.

Should you require more information about the conference, please visit our conference website www.isriti.akakom.ac.id you may also contact me at isriti@akakom.ac.id or texting by WhatsApp +62-815-7280-9394.

We look forward to meeting you at the conference.

Regards,

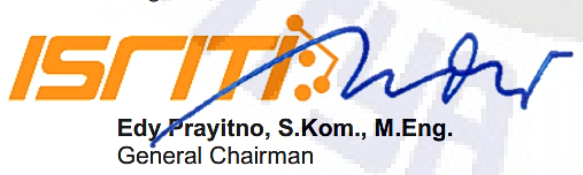

